\title{
The Exploration on Innovation of Analog Electronic Technology Course
}

\author{
LIU Jun ${ }^{1}$ WANG Qi ${ }^{2}$ \\ ${ }^{1}$ Institute of education science, Guizhou Normal University, Guiyang \\ ${ }^{2}$ Institute of physics and electronics, Guizhou Normal University, Guiyang
}

\begin{abstract}
This article carries on a detailed analysis and study on content, teaching methods and the problems of experimental teaching in the analog electronic technology(AET) course. It proposes the relevant scope, strategies and principles about teaching innovation of it. It introduces the contents and stages of this teaching innovation and constructs a new teaching model. Lastly, the article summaries the experiences and analyses the problems of innovation.
\end{abstract}

Keyword: AET Course, Innovation, Implementation

\section{Introduction}

analog electronic technology is a quite important professional basic course in the field of electronic information technology. It has higher abstract theory, learning is very difficult, the teaching effect is not good. With the rapid development of electronic technology, some new effective teaching methods should be tried and the course reform should be carried on. We did it.

\section{The Problem of Traditional Teach- ing Model}

1.1. Abstract Teaching Content and Unfavorable Teaching Effect

AET course is usually opened in the first grade in college, students often didn't learn circuit knowledge before. Meanwhile, the course's content is ab- stract and plenty. Teaching effect is not ideal.

\subsection{Insufficient Practical Teaching} Condition and Unsatisfied Training of Students' Practical Ability

In AET experiment, the electronic signals belonged to the weak signals are extremely susceptible to electromagnetic interference, thus the requirement for equipment is relatively high. The laboratory equipments often appear some problems, such as the improper design caused by interference signals, the experiment phenomenon can't remain stable caused by the components of poor thermal stability and even the experimental phenomenon can't be observed and so on.

1.3 Unreasonable Design of Experiment, Unachievable Purpose of Training

The existing experiments of AET course are mainly $\mathrm{v}$ replication experiment. Such experiments can't fully mobilize the enthusiasm and initiation of students, which suppresses they solve the questions, and will ultimately effect the cultivation of students' innovative ability.

2. Main Reform Aspects of AET Course

2.1 Basic Reform Idea of Teaching Theories' Conversion

2.1.1 Face The Forefront of Technological Development, Focus on The Development of New Technologies

Modern electronic technology development can be summarized as: Discrete

\footnotetext{
${ }^{*}$ This work was supported in part by Platform for innovation plan of Guiyang Science and Technology Department [No.(2012303)].
} 
components gather to the large scale integrated circuit and even huge scale integrated circuit. Analog circuit evolves to digital circuit. Artificial design evolves to computer automation design, and artificial control evolves to intelligent control. Therefore, in the design of curriculum content, new theory, new knowledge and new technology should be chosen based on the technical development.

2.1.2 Strengthen Engineering Application Training, Enhance Students' Practical Ability

If teaching content too much emphasizes on theoretical and subject aspect, ignoring the application aspect, it will inevitably cause the disconnection between theory and engineering practice, and also between school and society. It violates the fundamental goal of Engineering education. Therefore, the study of the basic knowledge requires penetrating the engineering technology contents, the theory should change from abstract to applicable, and the systematicness should transfer from discipline system to engineering system.

2.1.3 Emphasize Analysis Ability, Dilute Calculation Process

In the cultivable process of the students major in Electronic Information, we should think and deal with the problems from the point of actual engineering: It is called black box idea, which emphasizes on the external characteristics instead of pursuing the internal characteristics, and also emphasizes the approximate analysis instead of pursuing the theory calculation precision.

2.1.4 Strengthen Professional Training, Have A Definite Object in View

Different specialty of Electronic Information has different needs for a same course's knowledge, such as some specialties require the knowledge about the field effect tube and processing amplifying circuit, but some specialties require the knowledge about phase-locked loop and an arithmetic circuit. According to different needs, teachers should classify to teach.

2.1.5 Cultivate Students' Innovative Ability, Stimulate Students' Initiative and Creative Ability

For the increasingly fierce competition for talents in 21 Century, in order to adapt the rapid-renewal social environment, students should own strong innovation ability and self-learning ability.

\subsection{AET Reform Focuses on Teaching Reform}

2.2.1 Traditional Teaching Combines With Modern Education Technology

Traditional teaching methods often can make students get the knowledge points, but cannot make students understand knowledge well. The classroom needs a more vivid expression of electronic technology. In traditional classroom, modern education technology can use animated display principles to express abstract teaching content, can improve students interest in learning, and help students to understand the learning content.

2.2.2 Combination of Theory and Practice

Theoretical teaching pays attention to students' basis theoretical construction, Practical teaching pays attention to students' practical ability and knowledge application ability. Only theoretical teaching and practical teaching combine, students can really master the ability of flexible using of knowledge. The basic way to combine theoretical teaching with practical teaching is: Research the theory through the practice, then use the theory to guide the practice, finally through the practice to prove the theory.

\section{The Reform Principle of AET Course}

3.1 Essence is better than generalization. We should strengthen the integrated circuit explain and weaken the analysis of discrete elements. In the premise of explaining discrete circuit clearly, a new pattern will form, in which the integrated 
circuits are dominant and the discrete components and circuits are the foundation.

3.2 Inside is better than outside. We should focus on the analysis of the electronic device from an external circuit. For integrated circuit, students are required to know about its internal circuit structure diagram, and focus on the device and module's selection, matching connection and external characteristics.

3.3 Rough is better than detail. We should first determine the quality of definition, and then determine the quantity of analysis. For example of the chapter of "Frequency Response", the quantitative analysis of RC circuit derives the Bode plot, again from the physical concept, the qualitative explanation of the influence factors of frequency response leads to the frequency characteristic curve, then the quantitative analysis of various parameters of frequency characteristics derives the Bode plot, improving the teaching effects.

\subsection{Fact is better than virtualization.}

From the overall design of electronic system, the electronic system will be built on the basis of clarifying the local circuits, so as to get local fragmented knowledge together systemically.

\section{Practice of Teaching Reform on AET Course}

Through the above analysis, we design the reform thought, and construct the reform model. We believe that the reform should done from the following several aspects:

\subsection{Turn Abstract Knowledge into Concrete Knowledge by Modern Edu- cation Technology}

AET course is really abstract. It is the root reason why students feel it hard to learn. We use the computer animation and virtual reality technology. As shown in Fig. 1.

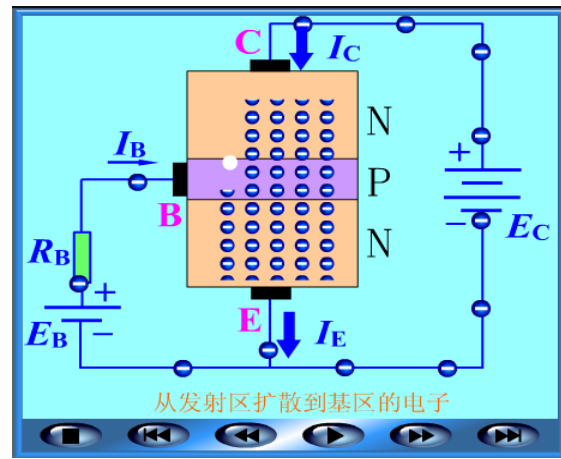

Fig.1: The Model of Three Transistor Internal Carrier Movement

Teachers can only through their own languages to describe the triode's internal carrier movement in traditional teaching. In the animation, we lay out the triode's electron and holes, and meanwhile clearly distribute the carrier movement's direction and quantity of emitting electrode, base electrode and collector electrode. It greatly performs the characteristics of triode's internal carrier movement. Students can have a very good understanding of the characteristics, the direction and the size of triode's internal carrier movement through the animation, and they can intuitively feel triode's realization about current amplified function. Thus it solves a big difficulty in learning. Students think while image will become only focus on the phenomenon of thinking. Students have accessed to no longer the abstract language, but a variety of specific process. This reform ensures students have a better understanding of the course content.

\subsection{The Teaching Mean of "Combina-} tion of Virtuality and Reality"

In teaching, we will use computer simulation software for demonstration on the ends of each unit circuit. Teachers consciously guide students through the circuit's design diagram to realize the circuit components, improving the students' ability to interpret the images. At the same 
time, teachers can use a variety of virtual test equipments to measure the circuit parameters, compare the measured results and the theoretical results, guide students to discuss the comparative results, and stimulate their interest in learning.

Table 1: The Reform Model of AET Course

\begin{tabular}{|c|c|c|c|c|c|c|}
\hline $\begin{array}{l}\text { First level } \\
\text { teaching- } \\
\text { reform }\end{array}$ & code & weight & $\begin{array}{l}\text { sequence } \\
\text { number }\end{array}$ & First level teaching-reform & code & Effect weight \\
\hline \multirow{3}{*}{$\begin{array}{l}\text { teaching } \\
\text { mode } \\
\text { reform }\end{array}$} & \multirow{3}{*}{$a_{1}$} & \multirow{3}{*}{0.3} & 1 & $\begin{array}{l}\begin{array}{l}\text { Focus on develop } \\
\text { students' investigative } \\
\text { thinking }\end{array} \\
\end{array}$ & $a_{11}$ & 0.12 \\
\hline & & & 2 & $\begin{array}{l}\text { Focus on knowledge's } \\
\text { summary and practice }\end{array}$ & $a_{12}$ & 0.1 \\
\hline & & & 3 & $\begin{array}{|lr|}\begin{array}{l}\text { Establish } \\
\text { relationship between } \\
\text { teachers and students }\end{array} \\
\end{array}$ & $a_{13}$ & 0.08 \\
\hline \multirow{3}{*}{$\begin{array}{l}\text { teaching } \\
\text { mean } \\
\text { reform }\end{array}$} & \multirow{3}{*}{$\mathrm{a}_{2}$} & \multirow{3}{*}{0.3} & 1 & \begin{tabular}{|l|}
$\begin{array}{l}\text { Make multimedia } \\
\text { courseware }\end{array}$ \\
\end{tabular} & $\mathrm{a}_{21}$ & 0.11 \\
\hline & & & 2 & \begin{tabular}{|l|}
$\begin{array}{l}\text { Use virtual simulation } \\
\text { software in Teaching }\end{array}$ \\
\end{tabular} & $a_{22}$ & 0.11 \\
\hline & & & 3 & $\begin{array}{l}\text { Focus on the } \\
\text { combination } \\
\text { traditional and modern }\end{array}$ & $\mathrm{a}_{23}$ & 0.08 \\
\hline \multirow{4}{*}{$\begin{array}{l}\text { Experim } \\
\text { ental } \\
\text { teaching } \\
\text { reform }\end{array}$} & \multirow{4}{*}{$a_{3}$} & \multirow{4}{*}{0.4} & 1 & \begin{tabular}{|l|}
$\begin{array}{l}\text { Establish four level } \\
\text { experimental system }\end{array}$ \\
\end{tabular} & $a_{31}$ & 0.12 \\
\hline & & & 2 & \begin{tabular}{|l|}
$\begin{array}{l}\text { Establish simulation } \\
\text { laboratory }\end{array}$ \\
\end{tabular} & $a_{32}$ & 0.09 \\
\hline & & & 3 & $\begin{array}{l}\text { Establish the opening } \\
\text { lab }\end{array}$ & $a_{33}$ & 0.09 \\
\hline & & & 4 & $\begin{array}{|lr|}\text { Develop } & \text { new } \\
\text { experimental project }\end{array}$ & $a_{34}$ & 0.1 \\
\hline
\end{tabular}

4.3 "Four Levels" Experiment Reform

AET experiment is divided into four levels: The first level is the basic skill training phase, it mainly trains students the basic experimental skills and the basic using methods of experiment instruments. The second level is the basic circuit function understanding phase, it mainly trains students to verify the characteristics of basic circuit functions. The third level is the simulation stage, it mainly tests some complicated circuit by electronic circuit simulation software, enhancing students' ability of software simulation; The fourth level is the independent development stage, it has two ways that teachers put forward the experimental items or students design the experiment project. The whole experiment process is entirely completed by students under teachers' guidance.
4.4. Strengthen The Construction of Opening Laboratory, Cultivate Students' Independent Learning Ability

We strengthened the construction of opening laboratory, and encouraged students to use their spare time to enter the lab. On the one hand it can make up for the insufficient experimental time, on the other hand it can greatly arouse students' enthusiasm, because students can design the experiment content and appointment time on teachers according to their own interest.

\section{The Reform Model of AET Course Based on AHP}

Analytic hierarchy process (AHP) is a quantitative and qualitative systemanalysis method, which is high logical, systematic, simple and practical. We set up a teaching-reform model of AET course after nearly two years' investigation for students, teachers and experts. As shown in Table 1, the first level of teaching-reform element $X=(a 1, a 2, a 3)=$ (teaching mode reform, teaching mean reform, examination method reform), each first teaching-reform element is divided into a plurality of the second level teaching-reform elements. The effort weights of teaching-reform elements are statistical data obtained from the effect questionnaires of AET course reform for students, teachers and some teaching experts in this field. The practical effect weights of teaching-reform elements of AET course can be judged in higher schools and higher colleges by using AHP and the questionnaires' statistics data.

\section{Effect and Summary}

In 2009 , this reform basically completed. People thought that, this course reform seized students' feature, the teaching content was rich, the information content was big, and the relationship with other professional courses was handled properly. The flexibility of teaching 
method and the diversity of teaching means can effectively improve the teaching quality.

In our institute, students in 2008 and 2009 grade markedly improved their grades of AET course, and the failure rate comparatively reduced. Students major in electronic information won a first prize, two second prize and two third prize in Guizhou province in $2009 \mathrm{Na}$ tional Undergraduate Electronic Design Contest.

Of course, through the implementation of the course reform, we also discovered many problems to be solved urgently:

- Too dependent on modern educational technology, restrict teachers Play

- Little investment, restrict the participant number of a group students

- Computer simulation impacts students' practical ability training

\section{Conclusion}

In general, through the experimental reform of AET course, we did a big adjustment of teaching contents, teaching means, teaching methods and other aspects. We achieved such transformation: "progressive" to "jump", " discipline system" to "application system", "micro part" to" macro entirety", "unification" to "classification" and "everthing" to "something". It greatly enriched the teaching model, and reduced the teaching difficulty. It improved the teaching quality. With the increase of teaching investments and the improvement of teaching conditions, the problems occurred in the reform process will be solved step by step.

\section{References}

[1]Shihuang Wang. The Software Application of LabVIEW in Analog Circuit [J]. College Physics Experiment, 2011.4(2):84-86

[2] Suxia He, Haixia Li, Xianding Wu. Research on innovation of analog electronic technology $[\mathrm{J}]$. Science and Technology Information,2010.5:511-512

[3] Xiulin Meng, Haiyin Xue, Xuehang $\mathrm{Xu}$. Study and Practice of Reform Onanalog Electronic Technology Course [J]. Journal of Electrical \& Electronic Engineering Education,2004.8(4):12-14

[4] Junrong Yan. The Teaching Application of Multisim10 simulation in Analog Electronic Technology Course[J].Journal of Science of Teachers' College and University, 2011.31:91-93

[5] Shibai Tong. Chenyin Hua. Simulation Electronic Technology Foundation [M]. Higher Education Press, Beijing. 